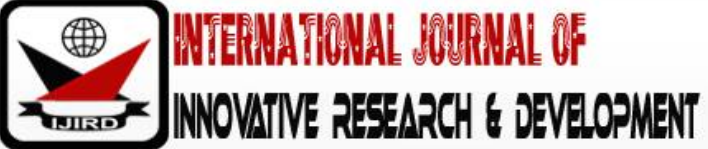

ISSN 2278 - 0211 (Online)

\section{Production of Paving Stone (Interlock) from Nylon Waste}

Omosebi Taiwo Oluwakemi
Lecturer, Department of Building Technology, Federal Polytechnic, Ado Ekiti, Nigeria
Fagbohun Joel Olayinka
Senior Lecturer, Department of Building Technology, Federal Polytechnic, Ado Ekiti, Nigeria
Dr. Aluko F. Isreal
Chief Lecturer, Department of Mechanical Engineering, Federal Polytechnic, Ado Ekiti, Nigeria
Ajayi B.A
Administrative Officer, Department of Registry, Federal Polytechnic, Ado Ekiti, Nigeria
Omosebi Duyilemi A.
Chief Laboratory Assistant, Department of Food Technology,
Federal Polytechnic, Ado Ekiti, Nigeria

\begin{abstract}
:
Nylon waste is a silent threat to the environment and its disposal leads to harmful effects on the environment, since waste nylon has low biodegradability. In this study, melted waste nylon aggregate was used as a binding agent in full replacement of cement with sharp sand aggregate in paving stones production. Test on water absorption, porosity, compressive strength and weather effect test were carried out on two different percentages of $30 \%$ and $70 \%$ (waste nylon and sand) ratio 7:3 and 3:7. The result shows that, the interlocks produced with 30\% waste nylon and 70\% sharp sand (3:7) absorbed water than the interlocks produced with 70\% nylon and 30\% sharp sand (7:3). Also, the interlocks containing $70 \%$ waste nylon and 30\% sharp sand (7:3) has higher compressive strength (stronger) than that of 30\% waste nylon and 70\% sharp sand (3:7) at different temperature. Base on the test, results, findings and conclusion, the following recommendations were made: Government should invest in using sand aggregate with waste nylon to make paving stone and create more awareness of this new innovation to the public, this could serve as waste reduction and employment opportunity.
\end{abstract}

Keywords: Paving stone, Nylon waste, Pollution, Interlock, aggregate

\section{Introduction}

Waste is now a global problem, and one that must be addressed in order to solve the world's resource and energy challenges. Plastics are made from limited resources such as petroleum, and huge advances are being made in the development of technologies to recycle plastic waste among other resources [1].

Plastic is one of the most commonly used materials in the modern era mainly due to its versatility and durability. It has also made life easier and better, but it is also very hazardous when not properly managed. Due to its nonbiodegradable nature it gets accumulated in the environment and causes a lot of problems [2]. Plastics are generally lightweight, non-corrosive, soft, flexible and nor biodegradable in nature. Its high heat and electrical insulation features make plastics an indispensable packaging material. Also plastics rank first in the total amount of global waste produced. Four percent of the oil produced in the world is used in the production of plastics. Plastics are mostly used in packaging and construction industries. Polyethylene (PE), Polypropylene (PP), Polyethylene Terephthalate (PET), Polyvinyl Chloride (PVC) and Polystyrene (PS) are the main types of plastics [3]. Waste plastics can be used for production of construction materials like building blocks, roof and floor tiles and also for bridge construction materials. This in turn optimizes the problem of waste material storage and the high cost of building materials. The waste plastics are incorporated with sand and other additives to form the construction materials [4]. Plastics account for $16 \%$ of chlorine in the environment and have 54 carcinogens. Polythene bags for disposal if burnt irresponsibly releases highly toxic gases like phosgene, carbon monoxide, chlorine, sulphur dioxide, nitrogen oxide, besides deadly dioxin. Polymer materials are steadily replacing natural materials like metal, timber, fiber and thus conserving the natural environment [5].

When solid waste is properly managed, it can be converted into an opportunity that helps to provide cheap raw materials, conserving natural resources, protect the environment, and promote sustainable development [3]. The behavior of dumping and/or inadequate management of solid wastes from various sectors has a negative significant impact on the environment elements, which will be added to the existing environmental problems. However, a better way of managing such very cheap waste to use it as a source of raw material to reduce the cost of the end product $[2,4]$. 
Since plastic waste has low biodegradability and is present in large quantities, disposal of plastic waste in open environment is considered to be a big problem [12]. Out of the total plastic waste that is generated, the majority of it is not reused and recycledas the process requires massive manpower and large processing cost [8]. Recently, many researchers have suggested the utilizationofplasticwasteinconcrete. Utilizingplastic waste in the construction industry has two advantages, namely: (i) Resolving the environmental problem of the disposal of waste; (ii) Reduction in construction costs as the waste is available in large quantities at low costs [8].

Cement as the significant established binder in development industry is extremely costly [14]. This is a direct result of extraordinary populace development and urbanization which have activated appeal of cement for a few development purposes to get together with the need to grow a vast number of structures [15]. In this manner the need to interface the void amongst request and high cost has justified the reason to research the utilization of less expensive elective sources such as Polyethylene Terephthalate (PET) [16,17] This research aims to explore the viability of using waste nylon from municipal solid waste in the place of cement to produce paving stones/interlock tiles. This research is strictly geared towards developing and producing valid and reliable paving stones from recycled waste nylon.

The main objective of this research work is examining the possibility of recycling nylon waste to produce paving stones or interlock. Using a waste nylon as a binding agent in replacement of cement in the production of paving stones is an effectively of converting waste nylon into building materials and have been studied and the paving stones obtained was shown to have a compressive strength than that the traditional made from cement. It also has a very low degree of porosity; it absorbed less water compare to cement paving stones.

\section{Methodology}

Material and equipment used in making pavement stone: The materials used in making pavement stone are sourced locally, they includes:

- Sand

- Nylon waste

- Sharp Metal mold

- Wood stirrer

- Sieve

- Hand glove

- Coal pot

- Nose mask

- Engine oil

\subsection{Procedure into Production of Paving Stone}

Steps involved in the production of paving stone are as follows:

\subsubsection{Collection of Raw Materials}

Most of the materials used for the research were made or collected locally. TheNylon Wastes was collected from Poli Water, Federal Polytechnic near digital library Ado-Ekiti. The metal mold was produced locally from a mechanical workshop; Obasanjo Innovation Center Federal Polytechnic Ado-Ekiti. The paving stone size is $5 \mathrm{~cm}$ thick made in different shapes, the wood stirrer was produced from the Department of Civil Engineering Federal Polytechnic Ado-Ekiti.

\subsubsection{Collection of Sand, Sieving and Drying Operation}

The fine aggregate (sand) was collected from Ajebamidele Ado-Ekiti. After collection, the sand was sieved to remove small stones and to get a smooth and fine surface. The sieved sand was dried with the use of an aluminum pot and a heat source (Fire wood). This was done to avoid water absorption which can affect the result.

\subsubsection{Melting of the Nylon and Curing Process}

An aluminum pot was placed on a heat source (fire wood) for about 5-10 minutes and g of the water sachets were added. The shredded Nylon waste was allowed to melt completely inside the aluminum pan at a temperature of 5000c. Fine aggregate (sand) was added and mixed thoroughly at stated ratio 7:3 and 3:7. The mixture was continuously stirred for 10 minutes to allow uniformity of the blended mixture. This mixture was poured into a $5 \mathrm{~cm}$ thick ironmold which has been lubricated with engine oil for easy removal. The edge of the mold was banged continuously, to allow even distribution of the mixture which aids the escape of bubbles that can cause a crack in the composite. The curing process involves the cooling of the composite material till it solidifies, this was done for 30 minutes (Fig.1). 


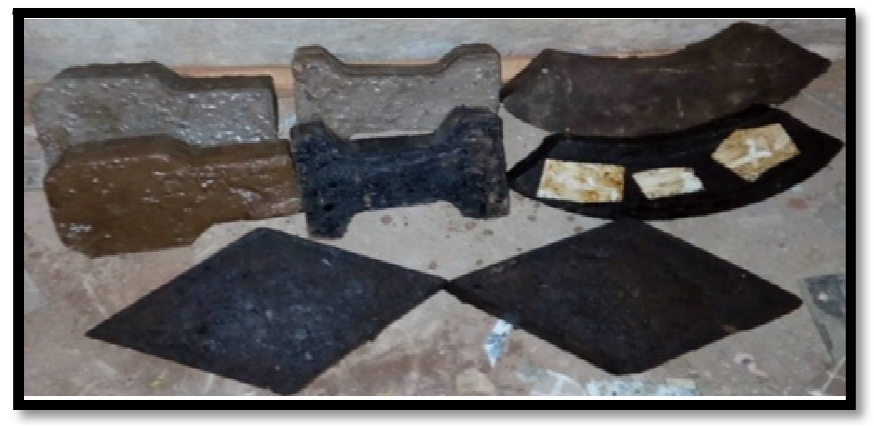

Figure 1: The Paving Stones Made from Recycled Nylon Waste

\subsection{Laboratory Tests on the Composite Produced}

Tests were carried out on the composite samples to ascertain the strength of the paving stone when compared with conventional paving stones. These tests include: Water absorption test, Porosity test, Compressive strength test, Weather effect test, Crushing strength test.

\subsubsection{Weather Effect Test}

This is done to know the effect of weather when the state of the atmosphere at a particular place and time as regards heat, cloudiness, wind, rain, etc. by expose some of the samples to ambient and some to laboratory temperature for 21 days, and the weight of the sample was checked with a weighing-balance before and after the test.

\subsubsection{Crushing Strength Test}

This is the greatest compressive stress that the paving stone can sustain without fracture. The crushing machine was calibrated in (KN) kilonewton. The sample was taken to the laboratory and with the used of the crushing machine this test was carried out on it.

\subsection{Liquid Limit Test}

\begin{tabular}{|c|c|c|c|c|}
\hline No of Trials & Trial 1 & Trial 2 & Trial 3 & Trial 4 \\
\hline Initial & 51 & 17 & 50 & 80 \\
\hline Final & 293 & 301 & 365 & 368 \\
\hline M.C & 56.0 & 59 & 61.1 & 70.7 \\
\hline
\end{tabular}

Table 1: Liquid Limit Test

Source: Fieldwork, 2019

Water Absorption: The results obtained shown the highest levels of water absorption amongst the composites were $30 \%$ nylon $(1.96 \%)$ while the lowest was at $70 \%$ nylon $(0.57 \%)$. This implies that $70 \%$ has the least affinity for water with absorption rate of $0.57 \%$. This simply showed that increase in nylon content led to corresponding decrease in water absorption up to $70 \%$ nylon which is in line with [23].

\subsection{Water Absorption Test}

\begin{tabular}{|c|c|c|}
\hline Can weight/M.C\% & $\begin{array}{c}\text { Sample A(7:3) } \\
\text { 70\% Nylon and 30\% Sand }\end{array}$ & $\begin{array}{c}\text { Sample B (3:7) } \\
\mathbf{3 0 \%} \text { Nylon and 70\% Sand }\end{array}$ \\
\hline W1 & 14.6 & 14.8 \\
\hline W2 & 187.5 & 199.4 \\
\hline W3 & 158.9 & 168.1 \\
\hline M.C\% & $0.57 \%$ & $1.96 \%$ \\
\hline
\end{tabular}

Table 2: Water Absorption Test

Source: Fieldwork, 2019

\subsection{Porosity Test}

\begin{tabular}{|c|c|c|}
\hline & $\begin{array}{c}\text { Sample A (3:7) } \\
\text { 30\% Nylon and 70\% Sand }\end{array}$ & $\begin{array}{c}\text { Sample B(7:3) } \\
\mathbf{7 0 \%} \text { Nylon and 30\% Sand }\end{array}$ \\
\hline Water Vol. & $350 \mathrm{ml}$ & $312 \mathrm{ml}$ \\
\hline Remnant Vol. & $177 \mathrm{ml}$ & $88 \mathrm{ml}$ \\
\hline Sand Vol. & $400 \mathrm{ml}$ & $400 \mathrm{ml}$ \\
\hline Porosity \% & $44.25 \%$ & $22 \%$ \\
\hline
\end{tabular}

Table 3: Porosity Test

Source: Fieldwork, 2019 


\subsection{Compressive Strength Test}

\begin{tabular}{|c|c|c|c|c|c|}
\hline S/N & $\begin{array}{c}\text { Samples } \\
\text { Description }\end{array}$ & $\begin{array}{c}\text { Weight } \\
\text { (kg) }\end{array}$ & Density (kg/) & $\begin{array}{c}\text { Load } \\
\text { (N) }\end{array}$ & $\begin{array}{c}\text { Compressive } \\
\text { Strength (N/ }\end{array}$ \\
\hline 1 & $\begin{array}{c}30 \% \text { nylon and 70\% } \\
\text { sand exposed to } \\
\text { ambient air }\end{array}$ & 1.15 & $8762 \times 10^{-5}$ & 110000 & $419 \times 10^{2}$ \\
\hline 2 & $\begin{array}{c}70 \% \text { nylon and 30\% } \\
\text { sand exposed to } \\
\text { ambient air }\end{array}$ & 1.28 & $9148 \times 10^{-5}$ & 130500 & $513 \times 10^{2}$ \\
\hline 3 & $\begin{array}{c}30 \% \text { nylon and 70\% } \\
\text { sand exposed } \\
\text { Laboratory room } \\
\text { temperature. }\end{array}$ & 0.86 & $2275 \times 10^{-7}$ & 72200 & $860 \times 10^{2}$ \\
\hline 4 & $\begin{array}{c}70 \% \text { Nylon and 30\% } \\
\text { sand exposed to } \\
\text { laboratory room } \\
\text { temperature. }\end{array}$ & 0.9 & $2434 \times 10^{-7}$ & 90000 & $1071 \times 10^{2}$ \\
\hline
\end{tabular}

Table 4: Compressive Strength Test

Source: Fieldwork, 2019

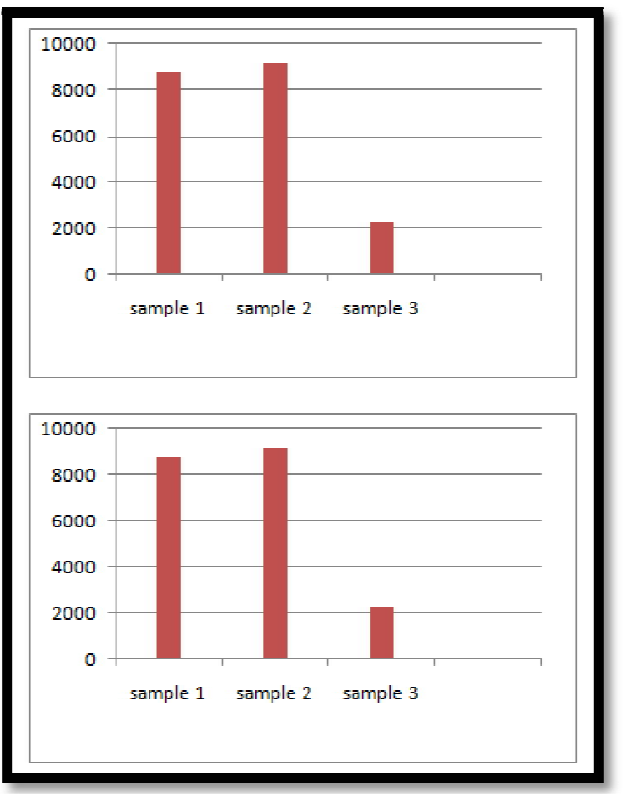

Figure 2: Weight of the Sample

- Density: From experiment conducted, the average density of the interlock specimens with lowest recorded density was at $70 \%(72.05 \mathrm{~kg} / \mathrm{m} 3)$ and the highest for nylon was $30 \%$ nylon $(130.20 \mathrm{~kg} / \mathrm{m} 3)$. From Figure 3, the graph indicates a rise in average density at 30\% nylon and a decrease at $70 \%$. When compared with control interlock, the composite interlock density decreases as the percentage of nylon increases.

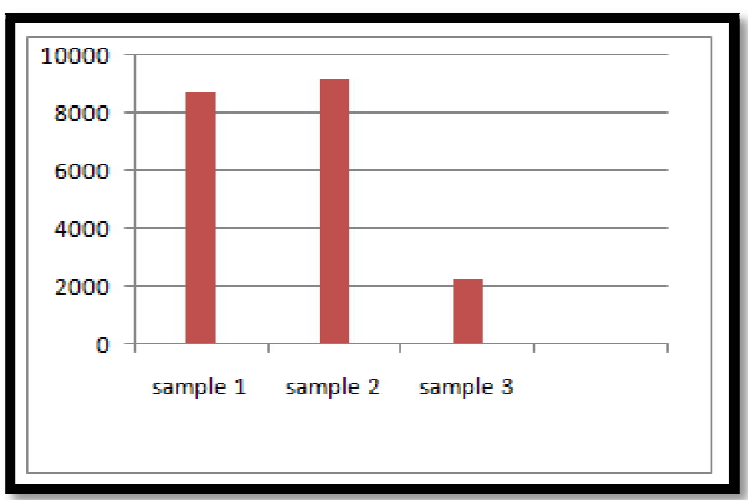

Figure 3: Density of the Samples $\left(\mathrm{Kg} / \mathrm{M}^{\wedge} 3\right)$ 


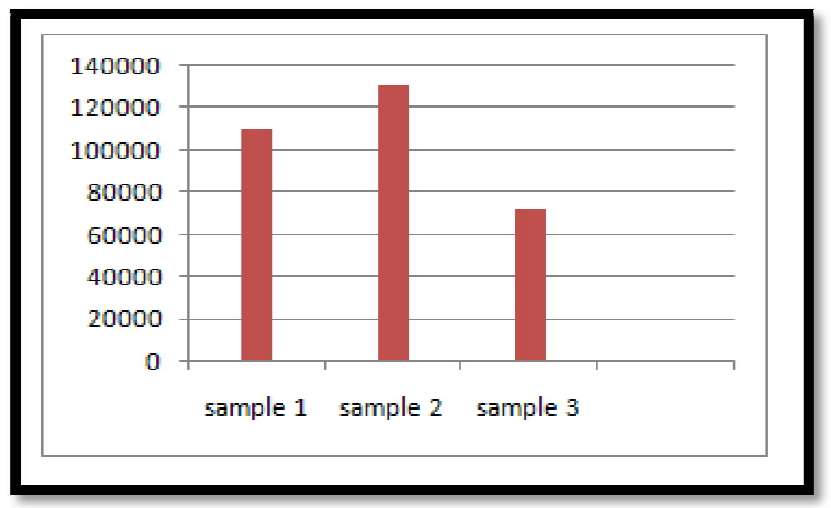

Figure 4: Load of the Samples

Particle Size Distribution Test Results: The sieve analysis was determined to know the aggregate gradation of fine sand. Figure 5 shows that the fine sand sample is well graded. Also, 2.670, 0.960, 2.7 values of coefficient of uniformity, Coefficient of gradation, and Fineness Modulus obtained from the study show that the aggregate is as well graded and is suitable for construction work.

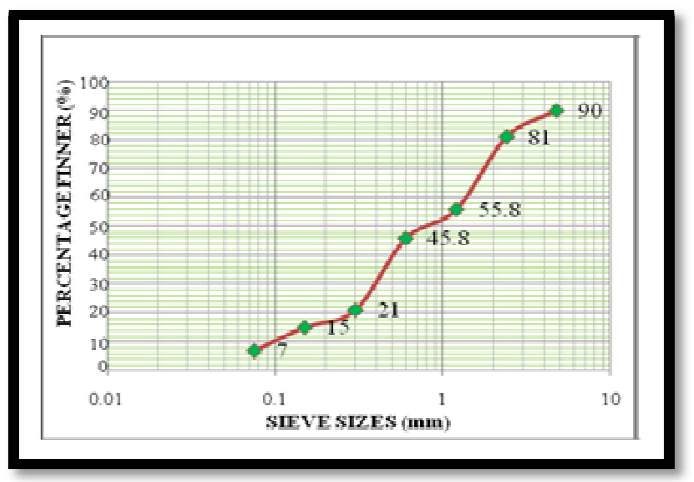

Figure 5: Particle Size Distribution Test

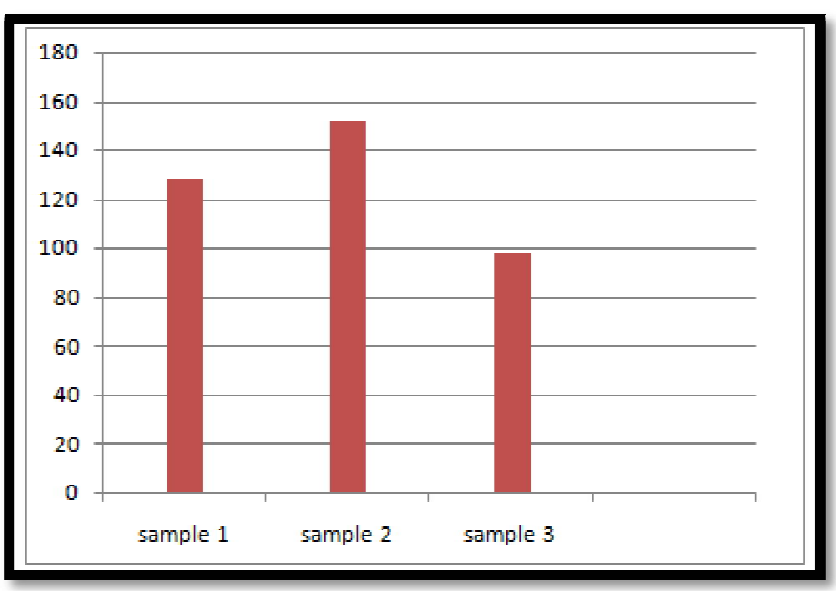

Figure 6: Compressive Strength $\left(\mathrm{N} / \mathrm{mm}^{\wedge} 2\right)$

Results and Findings: From the Figure, the maximum compressive load sustained by the Polypropylene/Rubber composite interlock is 22.70 tons. Therefore we can come to a conclusion that interlocks made of waste nylon will sustain a much higher load and compressive strength compared to the normal concrete interlocks. Also the results obtained from moisture content and porosity tests shows that the interlocks produced with $30 \%$ nylon and $70 \%$ sand absorbed water than the interlocks produced with $70 \%$ nylon and $30 \%$ sand.

\section{Conclusion}

This work effectively converts waste nylon into useful building material which is paving stones/interlocks which can effectively reduce the environmental pollution and further decreases the problem of waste nylon in the society. Rather than the waste nylon going into the landfill or incinerators, it can be used as construction materials at a much lower cost after undergoing certain specific processing. It also reduces the construction cost by eliminating the use of cement. From the compression testing results we come to know that waste nylon material when effectively mixed with sharp sand gives the highest compressive strength and sustains high compressive load. 


\section{References}

i. 'An Overview of Plastic Waste Management', Central Pollution Control Board, Delhi, 2012, pp. 1-22.

ii. Anslem E. O. Eneh, 'Application of Recycled Plastics and Its Components in the Built Environment', BEST: International Journal of Management, Information Technology and Engineering (BEST: IJMITE), ISSN 2348-0513, Vol. 3, Issue 3, Mar 2015, pp. 9-16.

iii. C. Rajesh, K.C. Manoj, G. Unnikrishnan, and E. Purushothaman, Adv. Polym. Technol., 32, S1 (2011).

iv. Dr. Pawan Sikka, 'Plastic Waste Management In India', Department of Science \& Technology, Government of India New Delhi, India, pp. 1 - 4.

v. EPA 430-R-11-005. Inventory of U.S. Greenhouse Gas Emissions and Sinks: (1990-2009), April 15, 2011. U.S. Environmental Protection Agency homepage. Available at: http://www. epa.gov.

vi. Melik Bekhiti, Habib Trouzine, Aissa Asroun, 'Properties of Waste Tire Rubber Powder', Engineering, Technology \& Applied Science Research, Vol. 4, No. 4, 2014, pp. 669-672.

vii. Noel Deepak Shiri, P. Varun Kajava, Ranjan H. V., Nikhil Lloyd Pais, Vikhyat M. Naik, 'Processing of Waste Plastics into Building Materials Using a Plastic Extruder and Compression Testing of Plastic Bricks', Journal ofMechanical Engineering and Automation, 2015, Vol.5(3B), pp. 39 - 42.

viii. Patil, P.S Mali, J.R Tapkire, G.V., and Kumavat, H.R. "Innovative techniques of waste plastic used in concrete mixture', International Journal of Research in Engineering and Technology, 3(9), pp.29\{31(2014).

ix. S.A.R. Abeer, D.E. El Nashar, S.L. Abd-El-Messieh, and K.N. Abd-El Nour, Mater. Des., 30, 3760 (2009).

x. Semiha Akçaözoğlu, 'Evaluation of waste plastics as recycled plastic composite materials', Edorium Journal of Waste Management, 2015; Vol. 1, pp. 16-19.

xi. Siti Aishah Wahid, Sullyfaizura Mohd Rawi, Norlia Md Desa, 'Utilization of Plastic Bottle Waste in Sand Bricks' , Journal of Basic and Applied Scientific Research, ISSN 2090-4304, , Vol. 5(1), 2015, pp. 35-44.

xii. Sadiq, M.M. and Khattak, M.R. \Literature review on different plastic waste materials use in concrete', Journal of Emerging Technologies and Innovative Research (JETIR), 2(6), pp. 1800\{1803 (2015).

xiii. Konin, A. (2011). Use of plastic wastes as a binding material in the manufacture of tiles: case of wastes with a basis of polypropylene. Materials and structures journal RILEM, 1381-1387.

xiv. Otuoze H. S., Amartey Y. D., Sada B. H., Ahmed H. A., Sanni M. I., \& Suleiman M. A. (2012). Characterization of sugar cane bagasse ash and Ordinary Portland Cement Blends in Concrete, in: Laryea S., Agyepong S.A., Leiringer R., Hughes W. (Eds). 4th West African Built Environment Research (WABER) Conference (pp. 1231-1237). Abuja, Nigeria: West Africa Built Environment Research (WABER) Conference.

xv. Ramaraj, A. P., \& Nagammal, A. N. (2014). Exploring the current practices of post-consumer PET bottles and the innovative applications as a sustainable building material. 30th International Plea Conference (pp. 16-18). Ahmedabad: Cept University Press.

xvi. Velumani P., \& Karthik S. G., (2017). Development of ecofriendly pressed roof tiles: A prologue study. International journal of scientific and engineering s research, 8 (12), 20302033

xvii. British Standard (BS EN ISO 62). (1999). Plastics-determination of water absorption. British Standard, United Kingdom.

xviii. American Society for Testing and Materials (ASTM C33). (2003). Standard Specification for Concrete Aggregates. West Conshohocken, PA, USA. 